\title{
Effect of Age and Socio Economic Status on the Quality of Life of Patients with Cervical Cancer Undertaking Chemotherapy at Dr. Moewardi Hospital Surakarta
}

\author{
Hidayah Nur Fadhilla'), Ambar Mudigdo'), Setyo Sri Rahardjo) \\ ${ }^{1)}$ Masters Program in Public Health,Universitas Sebelas Maret, Surakarta \\ 2)Faculty of Medicine,Universitas Sebelas Maret, Surakarta
}

\begin{abstract}
Background: Cervical cancer is a type of cancer affecting women with high incidence and mortality in the world.Patient with cervical cancer have to undertake prolonged sequential treatment and therefore may experience physical, physicological and social changes, which may affect their quality of life. This study aimed to examine effect of age and socio economic status on the quality of life of patients with cervical cancer undertaking chemotherapy at Dr. Moewardi hospital, Surakarta.

Subjects and Method: This was an analytic observational study with cross-sectional design. This study was conducted at Dr. Moewardi Hospital, Surakarta, from February to March 2017. A sample of 100 patients was selected by fixed disease sampling. The dependent variable was quality of life. The independent variables were age, education and family income. The data were collected by questionnaire and medical record, and then were analyzed by linear regression model.

Results: Education $\geq$ Senior High School $(b=10.25 ; 95 \% \mathrm{CI}=5.24$ to $15.26 ; \mathrm{p}<0.001)$ andfamily income $\geq$ Minimum Regional Wage $(b=0.47 ; 95 \% \mathrm{CI}=0.12$ to $0.83 ; \mathrm{p}=0.009)$ increased quality of life in patients with cervical cancer. Age $\geq 45$ years $(b=-0.53 ; 95 \% \mathrm{CI}=-0.84$ to $-0.21 ; \mathrm{p}=0.001)$ decreased quality of life in patients with cervical cancer.

Conclusion: The quality of life of patient with cervical cancer is determine by age, education, and family income.
\end{abstract}

Keywords: age, social economic status, quality of life, cervical cancer, chemotherapy

\section{Correspondence:}

Hidayah Nur Fadhilla. Masters Program in Public Health, Sebelas Maret University, Surakarta. Email: fadhillahidayah@student.uns.ac.id. Mobile: +6285729955373.

\section{BACKGROUND}

Cervical cancer is the most commonly found cancer on women with the highest morbidity and mortality rate in the world. The malignancy of cervical cancer is generated from Human Papilloma Virus (HPV) infection (Kemenkes, 2015).

According to a survey by Globocan (2012) annually, there were 527,600 new cases of invasive cancer and 265,700 deaths all over the world in 2012. According to American Cancer Society, it is estimated there were 12,990 new cases of invasive cancer and 4,120 deaths from cervical cancer in US in 2016 (Siegel et al., 2016). In
Indonesia cervical cancer is in the top place among the other types of cancer. The data from Basic Health Research (RISKESDAS) 2013 shows that cervical cancer share $0.8 \%$ or 98,692 of all cancer cases. Region with the highest prevalence of cervical cancer is East Java Province with as many as 21,313 and Central Java with as many as 19,990 (Kemenkes, 2015).

Cervical cancer is one of non communicable diseases that contributes to high mortality rate, in which the number of incidences is increasing that leads to economic, social, and psychological problems because its expensive treatment. 
Journal of Epidemiology and Public Health (2017), 2(1): 11-19

https://doi.org/10.26911/jepublichealth.2017.02.01.02

Cancer is described as a disease in a continuum which is stated from diagnosis, therapy, remission, recurrence or deterioration and terminal stadium. It makes patients difficult to accept the diagnosis and it takes an adjustment in each stadium and its treatment. In diagnostic phase, doctors are able to decide the appropriate procedure whether it is surgery, radiotherapy or chemotherapy (Arum, 2015).

Chemotherapy is one of the procedures that use medicines to terminate cancer cells. Chemotherapy also gives impact toward life such as physical and psychological impact (Arum, 2015). Physical impact that is generated post chemotherapy was nausea and vomiting, constipation, taste changes, weight lost, skin toxicity, alopecia, appetite loss, pain, peripheral neuropathy. Psychological impact that is possible to happen including anxiety, try to be normal, negative self esteem and giving up (Wardani, 2014).

The changes of bodily functions that happen on cervical cancer patients may generate self concept disorder where cervical cancer patients are becoming dependent to other people to meet their basic needs and the fulfillment of body parts functions (Fitriana dan Ambarini, 2012).

The quality of life can be illustrated with the well fulfilled human needs or how far an individual or group understands satisfaction or dissatisfaction toward various domains of life such as physical health, psychological state, autonomy level, social relationship, self confidence and their relationship with their environment (Costanza et al., 2007).

Age is a natural factor that can trigger cervical cancer. People who suffer from cervical cancer are women over the age of 40. The result of a study in 2001 showed that the peak age of cancer in Indonesia is
45-54 years. According Norwitz dan Schorge (2011) the most common ages for cervical cancer range from 41-54 years since it is the age of premenopause that has bigger possibility to suffer from multifocal lesion that is related to HPV which is one of cervical cancer's causes. Age affects the risk of cervical cancer incidences, in which the older the person means the longer she is exposed to carcinogens and the weaker the body immune is, that generates the risk for cervical cancer and also reduce the life quality of cervical cancer patients.

Patients' level of education affects the health condition of cervical cancer patients, in which patients with low level of education will be difficult to receive a relatively large amount of information about cervical cancer. Family's socioeconomic condition directly contributes in the process of treatment. Prolonged treatment has high effect of pain and worries over the treatment bill (Prastiwi, 2012). Family's involvement in helping patients to cope with the process of cancer treatment may help patients to attain optimal quality of life (Kusumaningrum et al., 2016).

In connection with a lot of cases of cervical cancer that undergo chemotherapy treatment and affects the quality of life, therefore the study aimed to explain the effect of age and socioeconomic status toward the quality of life of RSUD Dr. Moewardi, Surakarta.

\section{SUBJECTS AND METHOD \\ 1. Design of the Study}

The study use analytic observational study with cross sectional approach. The study was conducted in Dr. Moewardi Hospital, Surakarta from February up to March 2017.

\section{Population and Sample}

Population of study was all patients of cervical cancer that underwent treatment in Dr. Moewardi hospital, Surakarta. The 
subjects of the study were 100 cervical cancer patients who obtained chemotherapy treatment and met the inclusion also exclusion criteria. They were selected by using fixed disease sampling.

\section{Variables of the Study}

Independent variables of the study were age, education and family income. Dependent variable of the study was quality of life.

\section{Instruments of the Study}

Data collection was conducted by doing interview with questionnaires and medical record data. Questionnaires on quality of life were measured by using The European Organisation for Research and Treatment of Cancer (EORTC) QLQ-C30 and QLQCX24 that are specialized to evaluate the quality of life of cervical cancer patients (Perwitasari et al., 2011).

EORTC QLQ-C30 consists of some criteria that were 5 items of functional scale, 3 items of symptom scale, global health status, and 6 single items. Functional scales including physical function, role function, emotional function, cognitive function, and social function. For the symptom including fatigue, nausea \& vomiting and pain, whereas single item consists of dyspnoea, insomnia, appetite, constipation, diarrhea, and financial difficult.

QLQ-CX24 consists of 4 items of functional scale and 5 items of symptom scale. Functional scales includes body image, sexual activity, sexual enjoyment, sexual functioning. Symptom scales include symptom experience, lymphoedema, peripheral neuropathy, menopausal symptoms, sexual worry.

Higher scoring represents better functional and worse symptoms. Evaluation on quality of life can be concluded based on global health status (Aaronson et al, 1993; Frayer et al, 2001).

The researchers noticed the study ethics by giving inform consent to the subjects of the study to understand the purpose of the study, anonymity which means do not mention the name of study subjects and confidentiality which means keeping the privacy of information given by the study subjects

\section{Data Analysis}

Data processing was conducted by using editing technique by reexamining the instruments that were filled out during data collection; scoring was giving score on each question item; data coding was giving code onto data; data entry was inputting all coded data into computer file; and tabulating was data processing by making tables that gave statistical illustration.

Data analysis used SPSS version 22. Data analysis technique includes univariate analysis, bivariate analysis, and multivariate analysis by using multiple linear regression (Murti, 2013).

\section{RESULT}

Characteristics of study subjects in Table 1 were identified based on sociodemographic and clinical data as the result of univariate analysis. Data in Table 1 showed that out of 100 study subjects, most of them were $\geq 45$ years old (61.0\%) ranged from 35 up to 60 years old. Majority of the subjects suffered from stage III cervical cancer (56.0\%). Most of the education level of study subjects were $<$ Senior High School (61.0\%), and most of the study subjects were employed (58.0\%). Income of most of the study subjects, that was $70.0 \%$, was $\geq$ Regional Minimum Wage (Rp 1,534,985). Most of the study subjects were married (79.0\%).

Table 2 and 3 presented the value of quality of life of cervical cancer patients who underwent chemotherapy. The study result showed that the quality of life of cervical cancer patients based on QLQ-C30 measured from several aspects that were global health status. 
Journal of Epidemiology and Public Health (2017), 2(1): 11-19

https://doi.org/10.26911/jepublichealth.2017.02.01.02

Table 1. Characteristics of the study subjects

\begin{tabular}{llcc}
\hline \multicolumn{1}{c}{ Characteristics } & \multicolumn{1}{c}{ Criteria } & Frequency (n) & Percentage (\%) \\
\hline Age & <45 years old & 39 & 39.0 \\
& $\geq 45$ years old & 61 & 61.0 \\
Cancer stage & II & 44 & 44.0 \\
\multirow{3}{*}{ Education } & III & 56 & 56.0 \\
\multirow{2}{*}{ Occupation } & < High School & 61 & 61.0 \\
& 2 High School & 39 & 39.0 \\
Income & Unemployed & 42 & 42.0 \\
\multirow{2}{*}{ Marital Status } & Employed & 58 & 58.0 \\
& <Regional Minimum Wages & 30 & 30.0 \\
& 2Regional Minimum Wages & 70 & 70.0 \\
& Married & 79 & 79.0 \\
\hline
\end{tabular}

Table 2. Description of quality of life value based on EORTC QLQ-C3O

\begin{tabular}{|c|c|c|c|c|}
\hline Information & $\begin{array}{l}\text { Good } \\
\text { n (\%) }\end{array}$ & $\begin{array}{l}\text { Poor } \\
\text { n (\%) }\end{array}$ & Mean (SD) & Range \\
\hline Global Health Status & $42(42)$ & $58(58)$ & $57.33(17.37)$ & $25-91.67$ \\
\hline \multicolumn{5}{|l|}{ Functional scales ${ }^{1}$} \\
\hline Physical function ${ }^{1}$ & $49(49)$ & $51(51)$ & $58.47(19.29)$ & 20-100 \\
\hline Role function ${ }^{1}$ & $57(57)$ & $43(43)$ & $58.33(24.10)$ & $16.67-100$ \\
\hline Emotional function $^{1}$ & $44(44)$ & $56(56)$ & $75.25(22.89)$ & $8.33-100$ \\
\hline Cognitive function ${ }^{1}$ & $68(68)$ & $32(32)$ & $86.67(22.47)$ & $33.33-100$ \\
\hline Social function ${ }^{1}$ & $32(32)$ & $68(68)$ & $67.00(24.95)$ & $0-100$ \\
\hline \multicolumn{5}{|l|}{ Symptom scales ${ }^{2}$} \\
\hline Fatigue $^{2}$ & $55(55)$ & $45(45)$ & $40.33(18.05)$ & $0-100$ \\
\hline Nausea and vomitting 2 & $69(69)$ & $31(31)$ & $11.83(21.62)$ & $0-83.33$ \\
\hline Pain ${ }^{2}$ & $57(57)$ & $43(43)$ & $37.00(31.48)$ & $0-100$ \\
\hline dyspnoea $^{2}$ & $86(86)$ & $14(14)$ & $6.67(18.35)$ & $0-100$ \\
\hline Insomnia $^{2}$ & $51(51)$ & 49 (49) & $27.99(33.41)$ & $0-100$ \\
\hline Appetite loss 22 & $57(57)$ & $43(43)$ & $22.99(30.22)$ & $0-100$ \\
\hline Constipation ${ }^{2}$ & $70(70$ & $30(30)$ & $15.33(25.69)$ & $0-100$ \\
\hline Diarhea $^{2}$ & $93(93)$ & $7(7)$ & $3.33(13.81)$ & $0-100$ \\
\hline Financial difficulty ${ }^{2}$ & $36(36)$ & $64(64)$ & $33.33(31.78)$ & $0-100$ \\
\hline
\end{tabular}

Table 3. Distribution of quality of life value based on EORTC QLQ-CX24

\begin{tabular}{lcccc}
\hline \multicolumn{1}{c}{ Information } & $\begin{array}{l}\text { Good } \\
\text { n (\%) }\end{array}$ & $\begin{array}{c}\text { Poor } \\
\text { n (\%) }\end{array}$ & Mean (SD) & Range \\
\hline Function scales $^{1}$ & $70(70)$ & $30(30)$ & $86.67(21.78)$ & $0-100$ \\
Body Image $^{1}$ & $12(12)$ & $88(88)$ & $7.00(20.26)$ & $0-100$ \\
Sexual Activity $^{1}$ & $12(12)$ & $88(88)$ & $0.30(0.86)$ & $0-4.00$ \\
Sexual Enjoyment $^{1}$ & $12(12)$ & $88(88)$ & $3.58(12.49)$ & $0-66.67$ \\
Sexual Function $^{1}$ & & & & \\
Symptom scales $^{2}$ & $51(51)$ & $49(49)$ & $18.84(12.96)$ & $0-63.64$ \\
Experience $^{2}$ & $95(95)$ & $5(5)$ & $2.67(12.24)$ & $0-66.67$ \\
Lymphoedema $^{2}$ & $44(44)$ & $56(56)$ & $50.67(42.24)$ & $0-100$ \\
Peripheral neuropathy $^{2}$ & $49(49)$ & $51(51)$ & $30.67(35.03)$ & $0-100$ \\
Menopause $^{2}$ & $55(55.0)$ & $45(45.0)$ & $45.00(34.61)$ & $0-100$ \\
Sexual worry & & &
\end{tabular}


On global health status and functional status, the bigger the value means the increasing quality of life, whereas on symptoms scale and 6 items of single scale of disease impact, the bigger the value means the quality of life was worsening.

Table 2 showed that the domain of functional scales of cervical cancer patients such as physical function, emotional function, and social function were decreasing after obtaining chemotherapy treatment. Financial difficulty was increasing along with gradually implemented chemotherapy treatment. Table 3 showed that the decreasing sexual function, sexual activity and sexual enjoyment of cervical cancer patients were generated by the effect of the treatment. Worry was also arising because of the disease being suffered. Meanwhile, there was also an increase on symptom scale such as menopause and peripheral neuropathy.

Table 4 showed the data of bivariat analysis result that explained the effect of independent variables toward one dependent variable. Independent variables of the study were age, education and family income toward dependent variable that was the quality of life of cervical cancer patients who underwent chemotherapy.

Table 4. The analysis result of Pearson correlation about the effect of age and social economic status toward the quality of life of cervical cancer patients

\begin{tabular}{lcc}
\hline \multicolumn{1}{c}{ Independent Variables } & $\mathbf{p}$ & $\mathbf{R}$ \\
\hline Age (years) & $<0.001$ & -0.46 \\
Education & $<0.001$ & 0.74 \\
Family Income (rupiah) & $<0.001$ & 0.67 \\
\hline
\end{tabular}

Table 4 presented the analysis result of Pearson correlation test about the effect of independent variables toward dependent variable. Age was negatively affected to quality of life $(\mathrm{r}=-0.46 ; \mathrm{p}<0.001)$. Education $(\mathrm{r}=0.74 ; \mathrm{p}<0.001)$ and family income $(\mathrm{r}=0.67 ; \mathrm{p}<0.001)$ were positively affected to quality of life.

Table 5. The analysis result of multiple linear regression on age and socioeconomic status toward cervical cancer patients' quality of life.

\begin{tabular}{lcccc}
\hline \multirow{2}{*}{ Independent Variables } & Regression & \multicolumn{2}{c}{ CI 95\% } & \multirow{2}{c}{ p } \\
\cline { 3 - 4 } & Coefficient b & Lower Limit & Upper Limit & \\
\hline Intercept & 67.61 & 50.25 & 84.97 & $<0.001$ \\
Age $(\geq 45$ years) & -0.60 & -0.94 & -0.27 & $<0.001$ \\
Education ( $\geq$ High School) & 12.41 & 7.10 & 17.72 & $<0.001$ \\
Family Income ( $\geq$ Regional Minimum & 0.67 & 0.46 & 0.88 & $<0.001$ \\
Wage) & & & & \\
N observation $=100$ & & & & \\
AdjustedR $R^{2}=70.9 \%$ & & & & \\
p $<0.001$ & & & & \\
\hline
\end{tabular}

Table 5 presented the result of multivariate analysis between independent variables toward dependent variable. The result of analysis showed there was an effect that was statistically significant between age toward the quality of life, after controlling the effect of education and family income. Each year of increasing age decreased the quality of life by $0.60(\mathrm{~b}=-0.60 ; 95 \% \mathrm{CI}=-$ 0.94 to $-0.27 ; \mathrm{p}<0.001)$.

The result of analysis showed there was an effect that was statistically significant between education toward the quality of life, after controlling the effect of age and family income. High level of education ( $\geq$ High School) would increase the quality 
Journal of Epidemiology and Public Health (2017), 2(1): 11-19

https://doi.org/10.26911/jepublichealth.2017.02.01.02

of life by 12.41 compared to low level of education $(<$ High School) $(b=12.41 ; 95 \%$ $\mathrm{CI}=7.10$ to $17.72 ; \mathrm{p}<0.001)$.

The result of analysis showed there was an effect that was statistically significant between family income toward the quality of life, after controlling the effect of age and education. High family income ( $\geq$ Regional Minimum Wages) would increase the quality of life by 0.67 compared to low family income $(\mathrm{b}=0.67 ; 95 \% \mathrm{CI}=$ 0.46 to $0.88 ; \mathrm{p}<0.001)$.

The value of Adjusted $R^{2}$ was as much as $70.9 \%$ meant that three independent variables (age, education, family income) were able to explain the quality of life of cervical cancer patients who underwent chemotherapy by $70.9 \%$, the rest of $29.1 \%$ was explained by other factors outside the model of the study.

\section{DISCUSSION}

1. The Effect of Age toward the Quality of Life of Cervical Cancer Patients who Obtained Chemotherapy

The result of the study showed that there was negative effect of age toward the quality of life of cervical cancer patients who obtained chemotherapy and statistically significant. The older the patients would increase the risk for cervical cancer. It happens since the older the person the longer she is exposed to carcinogens as well as the weaker the immune system is, therefore it generates the risk for cervical cancer as well as reduce the quality of life of cervical cancer patients.

The subjects of the study ranged between 35 years old up to 60 years old, with the average age was 47 years, which belongs to productive age group and below the life expectancy age of Indonesia citizen which is currently up to 65 years. Productive age is the peak of the high risk for having cervical cancer, that is able to generate disorders toward the quality of life, physically as well as psychologically and sexual health. It is similar to what is stated by Susilawati (2013) that commonly cervical cancer patients are found at the age of above 40 , in which it is the vulnerable age toward health problems since degenerative process.

Most of the patients of cervical cancer in the study had poor quality of life because of the age factor, in which most of them were above 45 years old and also were affected by the effect of gradual chemotherapy treatment. There are several domains of quality of life that endure disorders such as on physical function, in which the older the person it affects physical activities since the strength loss of body muscle mass. It is in accordance with the study conducted by Einstein et al, (2011) that states $20 \%$ out of cervical cancer patients endure sexual function disorder including vaginal dryness, the fear to have sexual intercourse as the result of cancer.

\section{The Effect of Education toward the Quality of Life of Cervical Cancer Patients who Obtained Chemo- therapy}

The result of the study showed there was positive effect of education toward the quality of life of cervical cancer patients who obtained chemotherapy and statistically significant. Most of the patients of cervical cancer in the study had low level of education < High School. The study is in accordance with the study conducted by Susilawati (2013) and Perwitasari (2009) in which the majority of cervical cancer patients have low education. The level of education of cervical cancer patients is commonly low, it is also related to the low socio economic status. Low level of education greatly affects the knowledge and attitude toward the symptoms of cervical cancer. 
The high rate of cervical cancer cases in Indonesia is generated by the low coverage of preventive screening. It is affected by several factors such as Indonesian women are often reluctant to have their health checked because of ignorance, shame, fear and cost factor. It commonly happens since the low level of people's education and knowledge (Susilawati, 2013).

The result of the study conducted by Pradono dan Sulistyowati (2013), states that health status has positive and significant correlation with knowledge (51.6\%), healthy lifestyle behavior $48.2 \%$ ) and level of education (47.1\%). The duration of education may develop the effective life capacity which in the end will influence one's health, including working part time, able to run jobs well, improve economic welfare, able to self control, bigger social support, and healthy lifestyle.

Level of education also affect individual capability in controlling her life in which she will be motivated to maintain her health better with positive attitude by doing regular medical check up.

\section{Effect of Family Income toward the Quality of life of Cervical Cancer Patients who obtained Chemo- therapy}

The result of the study showed positive effect of family income toward the quality of life of cervical cancer patients who underwent chemotherapy and statistically significant. Most of the cervical cancer patients' family income in this study was above regional minimum wages of Surakarta City. The average cervical cancer patients came from middle lower class, whose treatment cost was covered by BPJS Healthcare Security from government. Most of the cervical cancer patients were not able to work and depended on either husband's or children's income.
Although being covered by BPJS Healthcare Security however the families were still facing financial difficulties, in which it took big amount of money for the operating cost during gradual and continuous medical examinations also chemotherapy treatment. It is in accordance with a study conducted by Wan et al., (2008), that financial difficulties are increasing significantly since after the patients were discharged from the hospitals, they will notice the amount of cost expensed during chemotherapy. The result of the study is similar with the previous study conducted in China, where almost all quality of life domains are decreasing significantly after chemotherapy.

The socio economic condition in general is related to various health problems being faced. In middle upper class the exposure of cancer will be bigger than middle lower class (Oemiati et al, 2011). Some of cervical cancer patients come during advanced stage and need rapid medical procedure that family do not have much choice and time in deciding what to do to the sick family members. In addition to the understanding toward the disease, treatment cost also becomes one special concern for cancer patients, thus will affect the quality of life of cancer patients (Prastiwi, 2012).

Cancer is the world's primary cause of death with a relatively heavy economic burden. The big impact toward the cost is seen from the primary treatment cost (including home care), outpatient care at the hospital, and inpatient care at the hospital such as medicines, oncologist care, radiation therapy, imaging diagnosis, and laboratory investigation Kovacevia et al., (2015).

Based on the study it can be concluded that the quality of life cervical cancer patients who obtain chemotherapy 
is affected by age $\leq 45$ years $(b=-0.60 ; 95 \%$ $\mathrm{CI}=-0.94$ to -0.27 ; $<$ 0.001); high level of education $\geq$ High School $(b=12.41 ; 95 \% \mathrm{CI}=$ 7.10 to 17.72; $\mathrm{p}<0.001$ ); and high family income $\geq$ Regional Minimum Wages $(b=$ $0.67 ; 95 \% \mathrm{CI}=0.46 \mathrm{~s}$ to $0.88 ; \mathrm{p}<0.001)$.

\section{FERERENCE}

Aaronson NK, Ahmedzai S, Bergman B, Bullinger M, Cull A, Duez NJ, Filiberti A, Flechtner H, Fleishman SB, de Haes JCJM, Kaasa S, Klee MC, Osoba D, Razavi D, Rofe PB, Schraub S, Sneeuw KCA, Sullivan M, Takeda F (1993). The European Organisation for Research and Treatment of Cancer QLQ-C30: A Quality of Life Instrument for use in International Clinical Trial in oncology. Journal of the National Cancer Institute. 85: 365375 .

Arum SP (2015). Kanker Serviks- Panduan Bagi Wanita Untuk Mengenal, Mencegah Dan Mengobati. Yogyakarta: Notebook.

Costanza R, Fisher B, Ali S, Beer C, Bond L, Boumans R, Danigelis NL, Dickinson J, Elliott C, Farley J, Gayer DE, Glenn LM, Hudspeth T, Mahoney D, McCahill L, Mclntosh B, Reed B, Rizvi SAT, Rizzo DM, Simpatico T, Snapp R (2007). Quality of Life: An approach Integrating Opportunitis, Human Needs, and Subjective well-being. Sciencedirect. Ecological Economics, 267-276.

Einstein MH, Joanne KR, Richard JC, Jacquelyn MS, James PH, Joseph PC (2011). Quality of life in cervical cancer survivors: Patient and provider perspectives on common complications of cervical cancer and treatment. Gynecologic Oncology.125(1): 163-7.

Fayers PM, Aaronson NK, Bjordal K, Groenvold M, Curran D, Bottomley A
(2001). The EORTC QLQ-C30 Scoring Manual (3rd Edition). European Organisation for Research and Treatment of Cancer. Brussels.

Fitriana NA, Ambarini TK (2012). Kualitas Hidup Pada Penderita Kanker Serviks Yang Menjalani Pengobatan Radioterapi. Jurnal Psikologi Klinis dan Kesehatan Mental 123.1(02).

Globocan (2012). Estimated Cancer Incidence, Mortality and Prevalence Worldwide. International Agency for Research on Cancer (IARC). WHO.

Kementrian Kesehatan RI (2013). Riset Kesehatan Dasar Tahun 2013. Jakarta.

(2015). Situasi Penyakit Kanker. Buletin Jendela Data dan Informasi Kesehatan, 1: 1-11. ISSN 2088-270X. Jakarta: Pusat Data dan Informasi Kementrian Kesehatan RI.

Kovaceia A, Dragojevic SV, Rancic N, Jurisevic M, Gutzwiller FS, Matter WK, Jakovljevic M (2015). End-ofLife Cost of Medical Care for Advanced Stage Cancer Patient. US National Library of Medicine National Institute of Health. 72 (4): 334-41.

Kusumaningrum T, Pradanie R, Yunitasari E, Kinanti S (2016). The Role of Family and Quality of Life in Patients with Cervical Cancer. Jurnal Ners. 11 (1): 112-117.

Murti B (2013). Desain dan Ukuran Sampel untuk Penelitian Kuantitatif dan Kualitatif di Bidang Kesehatan. Yogyakarta: Gadjah Mada University Press.

Norwitz E, Schorge J (2011). At a Glance Obstetri dan Ginokologi. Jakarta. Erlangga. Medical Series.

Oemiati R, Rahajeng E, Kristanto AY. (2007). Prevalensi Tumor dan beberapa faktor yang mempengaruhinya di Indonesia. Buletin Penelitian Kesehatan. 39 (4): 190-204. 
Perwitasari DA (2009). Pengukuran kualitas hidup pasien kanker sebelum dan sesudah kemoterapi dengan EORTC QLQ-C30 di RSUP Dr. Sardjito Yogyakarta. Majalah Farmasi Indonesia. $20(2), 68-72$.

Perwitasari DA, Atthobari J, Dwiprahasto I, Hakimi M, Gelderblom H, Putter H, Nortier JW, Guchelaar HJ, Kaptein AA (2011). Translation and validation of EORTC QLQ-C30 into Indonesian version for cancer patients in Indonesia. Jpn J Clin Oncol, 41(4): 519-29.

Pradono J, Sulistyowati N (2013). Hubungan antara Tingkat Pendidikan, Pengetahuan tentang Kesehatan Lingkungan, Perilaku Hidup Sehat dengan Status Kesehatan. Jakarta: Pusat Teknologi Intervensi Kesehatan Masyarakat, Badan Litbang Kemenkes RI.
Prastiwi TF (2012). Kualitas hidup penderita kanker. Journal Unnes. Universitas Negeri Semarang.

Siegel RL, Miller KD, Jemal A (2016). Cancer statistics 2016. CA: A Cancer Journal Clinicians. 66(1): 7-30

Susilawati D. (2013). Relationship between family support and anxiety level on palliative cervix cancer patients in RSUP Dr Sardjito Yogyakarta. Jurnal Keperawatan. ISSN 2086-3071. 4(2).

Wan C, Meng Q, Yang Z, Tu X, Feng C, Tang X, Zhang C (2008). Validation of the simplified Chinese version of EORTC QLQ-C30 from the measurements of five types of inpatients with cancer. Ann. Oncol. 19, 2053-2060. 